\title{
Samson (Samson)
}

\author{
Author: Kazimierz Brandys
}

First Published: 1948; first edition of the fragments, Kuźnica 1947

Translations: Czech (Samson, 1950); Slovak (Samson, 1950); Russian (Samson, in: Meždu vojnami, 1957); Swedish (Simson, 1957); Yiddish (Shimshn, 1958); Croatian (Samson, 1961); Italian (Sansone,1961); Bulgarian (Samson, 1962); Latvian (Samson, 1965); Italian (Sansone, 1994).

Film Adaptation: Samson, feature film; screenplay Kazimierz Brandys and Andrzej Wajda; film director Andrzej Wajda, premiered 11th of September, 1961.

About the Author: Kazimierz Brandys (1916-2000) was a Polish writer, essayist, and screenplay writer whose work was translated into many languages. Due to his Jewish background, he spent the war years on "Aryan papers" in Warsaw and Cracow. He made his debut as a writer after the war, joining a group of writers committed to the poetics of socialist realism as officially sanctioned by Communist authorities. He would later abandon this poetics in favour of the essay form and his own invention of "self-stories". Brandys was able to thwart the censors by working through the drugi obieg (underground publishing; literally, second circulation). He lived in New York and Paris. When martial law was declared in Poland in 1981, he decided to stay in Paris.

Further Important Publications: Drewniany koń (1946, The Wooden Horse; novel); Miasto niepokonane (1946, The Invincible City; novel); Nierzeczywistość (1977, Unreality; novel); Rondo (1982, Rondo; novel); Zapamiętane (1995; Remembered; novel).

\section{Content and Interpretation}

This is the first novel in Brandys' tetralogy Between the Wars, followed by Antigone, Troy Open City, and A Man Does Not Die, all of them written in the socialist realist style. The work presents an account of fascism during the years of war and occupation, followed by the victory over fascism and birth of a new mankind.

The story begins in 1934 and ends after the outbreak of World War II. The main character of the novel is Jakub Gold, a Jew living in Warsaw.

The first part of the novel takes place before the war. Jakub attends junior high school, where he develops a close friendship with a Pole, Tol Pankrat (who will be the main character of the subsequent novels in the series). They later study together at the university, where Jakub falls victim to antisemitic riots. During one riot, Jakub accidentally kills one of his attackers and is sentenced to three years in prison. The outbreak of World War II results in his early release. 
The plot then follows Jakub's escape from the ghetto, his years of wandering and misery, including a period in hiding in a basement and his decision to join the socialists. The story ends as Jakub is ambushed and killed during a guerrilla action.

\section{Main Topics and Problems}

Samson touches on a key for understanding Brandys' prose in the context of his Jewish background.

With the rise of antisemitism during the years leading up to World War II, we see how it increasingly affects the protagonist. Insofar as his appearance and background lead to his stigmatisation, his life is shaped by a series of painful experiences that teach him what it means to be Jewish. He does not feel his Jewishness directly, but rather becomes a Jew through the actions of others, namely as a consequence of their name-calling and aggression (Błoński, 2006, p. 23; Czyżak, 1998, p. 43).

The issue of being aware of one's Jewish fate can be found throughout Brandys' work. His protagonists face difficult experiences (or "hits") which underscore the exclusion of Jewish characters from the rest of the community, and which are manifest in various ways, including verbal and physical aggression and ostracism. This problem is most striking in Samson, where the main character is attacked in the university courtyard and, acting in self-defence, ends up killing one of his attackers with a stone.

In the world depicted by Brandys, aggression and antisemitism lead inevitably to killing, but it is significant that the entire sequence takes place in a university courtyard, which is to say, in the kind of place where one would expect such values as tolerance and understanding to be protected and upheld. Interestingly, the courtyard is also invoked as an arena for student skirmishes in Unreality (Nierzeczywistość) and Rondo, in which a protagonist is beaten by a nationalist militant while trying to help someone lying on the ground, and winds up getting struck unconscious himself.

Like the other novels in the Between Wars series, written in the socialist realist style, Samson does not tend to sustain contemporary readers' interest, and has not survived the test of time. However, it is still important for understanding the Jewish thread that runs through the writer's work. What is most striking in this novel is that it features a protagonist who finds connection through his own stigmatisation by others, a motif which will return in subsequent works by Brandys, including Little Book (Mała księga), and Postal Variations (Wariacje pocztowe), to become a signature of his work as a whole (Bikont, Szczęsna, 2006, p. 120; Foltyniak-Pękala, 2019, p. 234).

The theme of Jewishness recurs in various ways throughout Brandys' writings. The identity of the protagonist (but also of the writer) is constructed in the conceptual space between the obvious fact of being Polish and the experience, wrought with difficulty, of one's Jewish origin (Wołk, 1999, p. 104). Brandys draws on the concept of "Jewish-Polishness" while describing such experiences. He emphasises that both Polish and Jewish origins are important for him, or as he puts it in his novel Months (Miesiące): "Writing. Marriage. Country. Eroticism. Smart Jewry. My dreams. Everything 
stuck together. Reality started hurting a long time before I started hurting it in my books. I write about it. I come back to it over and over again. How to separate and enumerate it?” (Brandys, 1988, p. 448).

\section{Cited Works}

Bikont, A., Szczęsna, J. (2006). Lawina i kamienie. Pisarze wobec komunizmu. Warszawa: Prószyński i S-ka. Błoński, J. (2006). Biedni Polacy patrzą na getto. Kraków: Wydawnictwo Literackie. Czyżak, A. (1998). Kazimierz Brandys. Poznań: Rebis. Brandys, K. (1988). Miesiące 1982-84. Warszawa: Nowa. Kazimierz Brandys. Warszawa: Czytelnik. Foltyniak-Pękala, A. (2019). Autopowieść. Dyskurs autobiograficzny w prozie Kazimierza Brandysa. Kraków: Universitas. Wołk, M. (1999). Tekst w dwóch kontekstach. Narracja pierwszoosobowa w powieściach Kazimierza Brandysa. Torun: Wydawnictwo Naukowe Uniwersytetu w Toruniu.

\section{Further References}

Bruner J. (1991), The Narrative Construction of Reality. Critical Inquiry, (18), pp. 1-21. Clark, T. (1993). The New Man's Body. A Motif in Early Soviet Culture. In: M. C. Bown, B. Taylor, eds., Art of the Soviets: Painting, Sculpture and Architecture in a One-Party State 1919-1922. Manchester: University Press, pp. 33-49. Jarosiński, Z. (1999). Nadwiślański socrealizm. Warszawa: Instytut Badań Literackich. Maciąg, M. (1961). 16 pytań: portrety polskich prozaików wspótczesnych. Kraków: Wydawnictwo Literackie. Wołk, M. (2008). Sygnatury ukryte. Rudnicki, Stryjkowski, Brandys. In: M. Cieśla-Korytowska, I. Puchalska, M. Siwiec, M., eds., Oblicza Narcyza. Obecność autora w dziele. Kraków: Universitas, pp. 345-367. Ziomek, J. (1964). Kazimierz Brandys. Warszawa: Wiedza Powszechna. 